ВІСНИК

ОДЕСЬКОГО НАЦІОНАЛЬНОГО

МОРСЬКОГО УНІВЕРСИТЕТУ
HERALD

OF THE ODESSA NATIONAL

MARITIME UNIVERSITY № 1 (61), 2020

уУДК 629.5

DOI 10.47049/2226-1893-2020-1-55-69

\title{
АНАЛІЗ СТАНУ ТА ПРОБЛЕМ РОЗРАХУНКУ \\ НАПРУЖЕНО-ДЕФОРМОВАНОГО СТАНУ \\ ТОРОЇДАЛЬНОГО МІЦНОГО КОРПУСУ ДЛЯ ПІДВОДНИХ АПАРАТІВ
}

С.Ф. Присташ

аспірант кафедри

«Проектування та виробництво конструкцій із композиційних матеріалів»

Начіональний університет кораблебудування ім. адм. Макарова

Анотація. В роботі проведено аналіз стану та проблем розрахунку напружено-деформованого стану тороїдальних міцних корпусів із полімерних композииійних матеріалів для підводних апаратів.

Ключові слова: напружено-деформований стан, тор, міџний корпус, полімерні композиційні матеріали.

УДК 629.5

DOI 10.47049/2226-1893-2020-1-55-69

\section{АНАЛИЗ СОСТОЯНИЯ И ПРОБЛЕМ РЕШЕНИЯ НАПРЯЖЕННО-ДЕФОРМИРОВАННОГО СОСТОЯНИЯ ТОРОИДАЛЬНОГО ПРОЧНОГО КОРПУСА ДЛЯ ПОДВОДНИХ АППАРАТОВ}

С.Ф. Присташ

аспирант кафедры

«Проектирование и производство конструкций из композиционных материалов»

Национальный университет кораблестроения им. адм. Макарова

Аннотация. В работе проведен анализ состояния и проблем решения напряженно-деформированного состояния тороидальных прочных корпусов из полимерных композиционных материалов для подводных аппаратов.

Ключевые слова: напряженно-деформированное состояние, тор, прочный корпус, полимерные композиционные материалы.

UDC 629.5

DOI 10.47049/2226-1893-2020-1-55-69

ANALYSIS OF THE STATE AND PROBLEMS OF EVALUATION

OF STRESSED-DEFORMED STATE OF TOROIDAL PRESSURE HULL FOR UNDERWATER APPARATS

$$
\text { S. Prystash }
$$

Postgraduate of the department

of «Design and production of structures from composite materials»

Admiral Makarov National University of Shipbuilding

Abstract. The analysis of the state and problems of evaluation of stresseddeformed state of toroidal pressure hulls, made of polymer composite materials, for underwater apparats.

Keywords: stressed-deformed state, torus, pressure hull, polymer composite materials.

() Присташ С.Ф., 2019 
Вступ. При освоєнні океанічних глибин широко застосовуються населені і ненаселені глибоководні апарати. Основними компонентами яких є: 1) міцний корпус, що захищає від дії зовнішнього тиску; 2) обладнання для спостереження; 3) елементи плавучості; 4) джерело енергії та перетворювач потужності (рушійних комплекс). Ці компоненти, взяті як окремо, так і разом, складають значну частину початкової вартості під-водного апарату та накладають обмеження на його робочі характерис-тики, розміри і об'єми.

Міцний корпус - це один із найбільших та важких компонентів підводних апаратів. Корпус повинен бути компактним та легким, настільки наскільки це можливо, при цьому мати відповідну міцність та стійкість, щоб мати змогу протистояти зовнішньому гідростатичному тиску. При проектуванні міцного корпусу необхідно обрати його форму, матеріал, товщину корпусу, що визначається із робочої глибини занурення та коефіцієнта безпеки, а також спроектувати ілюмінатори, люки, торцеві кришки, гермовводи.

Мета статті - проаналізувати стан та проблеми розрахунку напружено-деформованого стану тороїдального міцного корпусу для підводних апаратів виготовлених із полімерних композиційних матеріалів.

Основний матеріал. Міцні корпуси підводних апаратів зазвичай мають форму кругових циліндрів, сфер, еліпсоїдів, конусів та куполів. Порівняння різних форм міцних корпусів представлено в табл. 1 [1].

Із аналізу таблиці видно, що сферична оболонка $\epsilon$ найбільш ефективним міцним корпусом, оскільки такий корпус поводить себе як ідеальна мембрана. Населені підводні апарати, які доходили до дна Марианської впадини (11 000 м), мали сферичний міцний корпус. Але, незважаючи на цей факт, більшість підводних апаратів та підводних човнів не спроектовані на основі сферичної оболонки, тому що такі апарати не підходять по гідростатичним характеристикам, можуть мати труднощі при стиковці та внутрішній простір сфери неефективний для розміщення пасажирів і обладнання.

Тому міцний корпус підводних технічних засобів $є$ однією із самих складних конструкцій при проектуванні.

Відомі оригінальні проекти [2-8] підводних апаратів, суден та підводних бурових платформ, станцій з міцним корпусом у формі тору (рис.1) поява яких обумовлена рядом переваг тороїдальної форми. Тороїдальний міцний корпус володіє гідродинамічною формою, яка має велику остійність на поверхні води та на глибині. За рахунок подвійної кривизни тору товщина стінки міцного корпусу на його основі в порівнянні 3 циліндричною формою може бути зменшена в 1,5-2 рази, що тим самим дозволить збільшити глибину занурення [2]. 
Порівняння форм міцних корпусів підводних апаратів

\begin{tabular}{|c|c|c|}
\hline & Переваги & Недоліки \\
\hline Сфера & $\begin{array}{l}\text { 1. Найкраще відношення маси } \\
\text { до водотоннажності. } \\
\text { 2. Легкість створення отворів } \\
\text { в корпусі. } \\
\text { 3. Аналіз напруженого стану } \\
\text { більш точний та найменш } \\
\text { складний. }\end{array}$ & $\begin{array}{l}\text { 1. Складність внутріш- } \\
\text { нього розміщення. } \\
\text { 2. Великий гідродинаміч- } \\
\text { ний опір руху. }\end{array}$ \\
\hline Еліпс & $\begin{array}{l}\text { 1. Хороше відношення маси } \\
\text { до водотоннажності. } \\
\text { 2. Більш ефективне внутрішнє } \\
\text { розміщення. } \\
\text { 3. Легкість створення отворів } \\
\text { в корпусі. } \\
\end{array}$ & $\begin{array}{l}\text { 1. Більша вартість виго- } \\
\text { товлення. } \\
\text { 2. Складний розрахунок } \\
\text { конструкцій. }\end{array}$ \\
\hline Циліндр & $\begin{array}{l}\text { 1. Найбільш легкий в виготов- } \\
\text { ленні. } \\
\text { 2. Найбільш ефективне внут- } \\
\text { рішнє розміщення. } \\
\text { 3. Малий гідростатичний опір } \\
\text { руху. } \\
\text { 4. Круговий циліндр володіє } \\
\text { хорошою гідродинамічною } \\
\text { формою, кращою, ніж сфера } \\
\text { того ж об’єму. } \\
\text { 5. Додатковий об’єм внутріш- } \\
\text { нього корпусу може бути } \\
\text { досягнутий за рахунок } \\
\text { збільшення довжини } \\
\text { циліндра. }\end{array}$ & $\begin{array}{l}\text { 1. Найменш ефективне } \\
\text { відношення маси до } \\
\text { водотоннажності. } \\
\text { 2. Потребуються ребра } \\
\text { жорсткості на глиби } \\
\text { нах нижче } 300 \text { м. } \\
\text { 3. Складний розрахунок } \\
\text { конструкції з отвора- } \\
\text { ми в циліндричному } \\
\text { корпусі. } \\
\text { 4. Підводні апарати і чов- } \\
\text { ни з циліндричним кор- } \\
\text { пусом, не можуть легко } \\
\text { рухатись та маневру- } \\
\text { вати в 3-х напрямках. }\end{array}$ \\
\hline Top & $\begin{array}{ll}\text { 1. } & \text { Хороша гідродинамічна } \\
\text { форма. } \\
\text { 2. Можливість виготовлення } \\
\text { методом намотування із КМ. } \\
\text { 3. Тороїди малочутливі до } \\
\text { початкової недосконалості } \\
\text { геометрії. }\end{array}$ & $\begin{array}{l}\text { 1. Складний розрахунок } \\
\text { конструкції з отворами } \\
\text { в тороїдальному } \\
\text { корпусі. }\end{array}$ \\
\hline
\end{tabular}



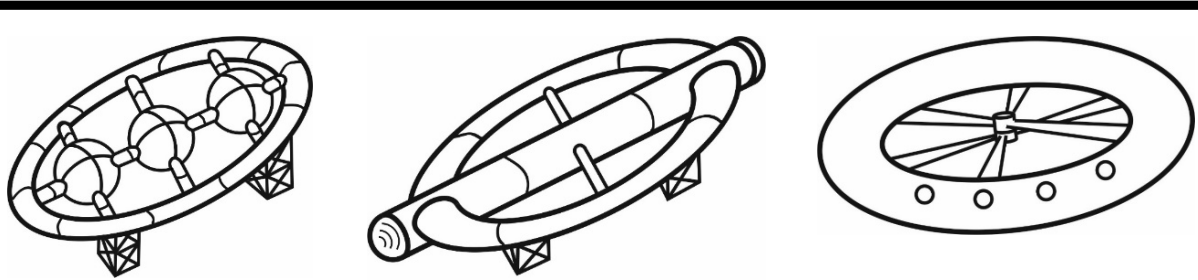

Рис. 1. Проекти підводних бурових станцій та апарату

В 1988 році фірма Mar.Ital побудувала самохідний малий рятівний підводний човен. Корпус якого зібрано з тороїдальних зігнутих зварних стальних труб (рис. 2) (зовнішній діаметр - 7,5 м та товщина стінок близько одного сантиметра). Глибина занурення - до 400 м [3].

Автором [4] запропонована модель великогабаритного підводного технічного апарату (рис. 2), міцний корпус якого має форму тору. У вільному центральному просторі тороїдального міцного корпусу встановлено вертикальний гвинт 3 лопатями, що починають виконувати обертальний рух завдяки лінійному двигуну.

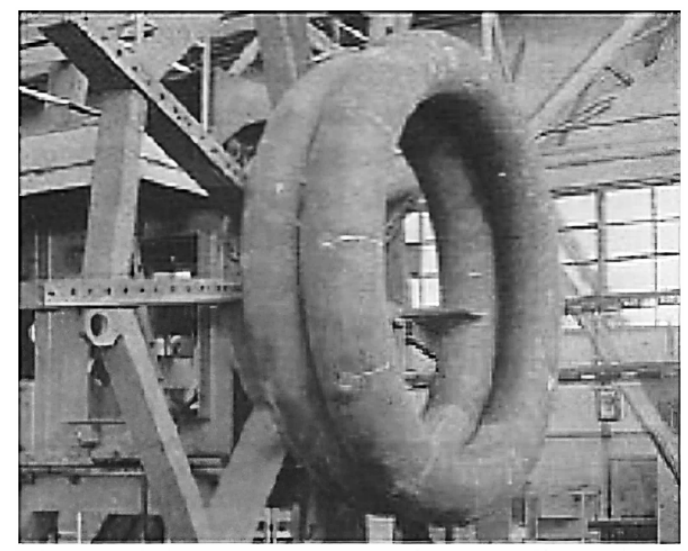

Рис. 2. Зварювання тороїдальних елементів

В роботі [5] описується проект автономного підводного судна, що складається з однієї або декількох тороїдальних оболонок в якості міцних корпусів, розміщених в обтічному легкому корпусі. Така конструкція буде мати ефект «крила», що зменшить опір руху в водному середовищі та збільшить маневреність безлюдного підводного апарату. А оснащення такого підводного апарату, наприклад, комплексом спеціально орієнтованих водометних рушіїв дозволить здійснювати повздовжній рух, просторове маневрування та стабілізацію апарату в водному середовищі при виконанні ним робочих операцій. Переріз тороїдальної оболонки 
ВІСНИК

ОДЕСЬКОГО НАЦІОНАЛЬНОГО

МОРСЬКОГО УНІВЕРСИТЕТУ

№ 1 (61), 2020
HERALD

OF THE ODESSA NATIONAL

MARITIME UNIVERSITY № 1 (61), 2020

може бути круговим або еліптичним, в якому найбільша піввісь розташована вздовж центральної вісі тороїдальної оболонки. Тороїдальні міцні кор-пуси передбачається виробляти методом намотування із композиційних матеріалів (КМ).

Вибір авторами [4-5] тороїдальної оболонки в якості міцного корпусу обумовлено рядом іï переваг. Дослідження статичної та динамічної стійкості сталевих тороїдальних оболонок показали, що тороїди малочутливі до початкової недосконалості геометрії, що прямо протилежно до чутливості півсфер, торцевих поверхонь різних форм та циліндричних оболонок, які є стандартними геометричними формами для міцних корпусів. А виробництво тороїдальних та циліндричних міцних корпусів методом намотування дозволяє отримати ідеально круглий переріз та $є$ технологічно більш простою процедурою, ніж виготовлення ïx 3 металу шляхом зварювання 3 попередньо зігнутих або штампованих листів заготовок, а також зменшити масу підводного апарату.

Також розробляються нові проекти підводних лабораторій та глибоководних платформ, міцним корпусом яких буде одна або декілька великогабаритних тороїдальних оболонок. Наприклад, Westinghouse Electric Corp. запропоновано проект жилої підводної станції, міцний корпус якої має форму тору з зовнішнім діаметром 12,2 м 3 круговим перерізом радіуса 1,525 м. Станція або лежить на півсферичній бетонній основі на морському дні або пришвартована до цієї основи та підіймається на потрібну глибину. Додаткові тороїдальні модулі можуть бути приєднані вертикально для розширення можливостей станції. Станція 3 робочою глибиною до 1800 м може використовуватись для комерційного дослід-ження океану, наприклад для розробки родовищ [6; 7]. Інтенсивна розробка конструкцій підводних нафтових платформ, які здатні працювати на глибинах більше 3000 м, розпочалась після відкриття на дні океану величезних запасів метану, який знаходиться в замороженому стані [8]. В більшості проектів таких платформ, міцний корпус підводної бурової платформи для добування метану запропоновано в формі тору [8]. Аналогічна конструкція підводної платформи описана Россом та Лафолу-Лейном. Такі підводні конструкції можуть тривалий час знаходитись під водою стаціонарно з можливістю повільно рухатись (рис. 1). Необхідною умовою при цьому $є$ хороша гідродинамічна форма тору.

Авторами [8] проведено порівняння матеріалів для підводної бурової платформи в формі тору з глибиною експлуатації до 11000 м. Виходячи $з$ показників питомої міцності для різних матеріалів, питома міцність КМ (вуглепластика та склопластика) набагато вище, ніж сама міцна сталь. Так при зануренні міцного корпусу підводного засобу зовнішній тиск на корпус збільшується більш менш лінійно. I щоб протистояти цьому зовнішньому тиску потрібно збільшувати товщину стінки міцного корпусу. А при використанні металу міцний корпус стає 
настільки важким, що не буде мати достатньої плавучості, і в результаті без додаткової плавучості, апарат потоне. Тому для занурення на великі глибини необхідно забезпечити максимальну питому міцність. Виготовлення таких великогабаритних підводних платформ передбачається методом намотування із КМ. Але при цьому оболонка буде дуже товстою. Для реалізації такого проекту необхідні розробка технології намотування товстостінної композиційної оболонки, дослідження в області оптимального проектування і високоміцного волокна та сполучника.

В 1991 році Сміт [8] показав, що безнабірний круговий циліндр, зроблений із склопластика (СП), може занурюватись до 8 разів глибше, ніж аналогічний, спроектований зі сталі, а із вуглепластика (ВП) - 10 разів глибше.

Велика кількість змінних при проектуванні тороїдального корпусу та складний напружений стан, який притаманний композитам, роблять виготовлення такого корпусу досить трудомістким, ніж із звичайних ізотропних матеріалів, деякі питання у цьому напрямку залишаються до цих пір не вирішеними, тому потребують подальшого дослідження.

Основним навантаженням на тороїдальний міцний корпусу підводного апарату є гідростатичний тиск, який викликає його рівномірне статичне стискання і значні стискаючі напруження. Оскільки задача стійкості міцного корпусу вирішена [9], виникає необхідність у визначенні напружено-деформованого стану (НДС) при розрахунку на міцність. НДС замкненої в круговому та меридіанному напрямках тороїдальної оболонки, що знаходиться під дією зовнішнього рівномірного тиску, є предметом ряду досліджень. Актуальність досліджень НДС таких оболонок обумовлена широким використанням тонкостінних оболонкових конструкцій із нових багатошарових КМ, виконаних в окремому випадку методом намотування волокном, що дозволяє досягти найбільших значень коефіцієнта заповнення об'єму (КЗО) (до 70-74,05 \%), яке реалізує властивості армуючого наповнювача в складі матеріалу в повній мipi.

Основоположною роботою по розрахунку ізотропних тороїдальних оболонок з постійною товщиною (рис. 3), в тому числі i підкріплених ребрами, є робота Черних К.Ф. та Шаміной В.О. [10], де викладені основні методи розрахунку.

В роботі вказано, що при $k$, не дуже близьких до 1 , для визначення напружень можна використовувати безмоментне рішення Фепля

$$
\begin{aligned}
\sigma_{\theta}=\sigma_{\theta}^{(p)} & =-\frac{1+0,5 \cdot k \cdot \sin \theta}{1+k \cdot \sin \theta} \cdot \frac{p \cdot a}{h} \\
\sigma_{\phi} & =\sigma_{\phi}^{(q)}=-\frac{1}{2} \cdot \frac{p \cdot a}{h}
\end{aligned}
$$




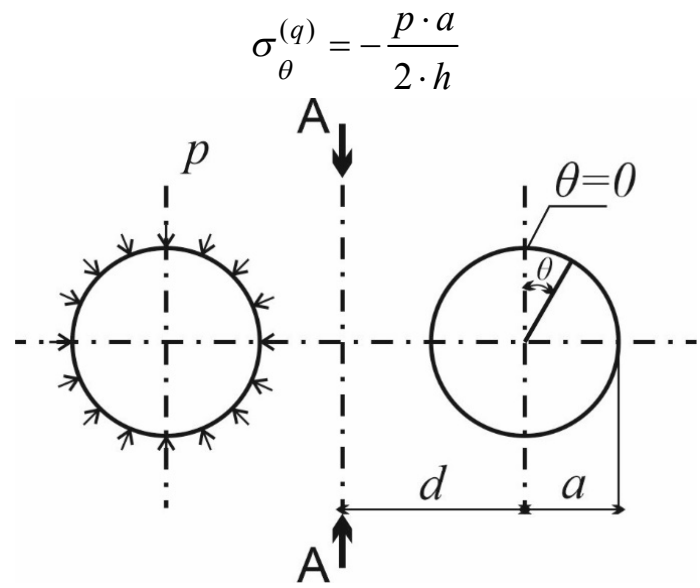

Рис. 3. Геометричні параметри тороїдальної оболонки

Згідно до безмоментного рішення найбільш небезпечною точкою $є$ точка на внутрішньому екваторі $\left(\theta=270^{\circ}\right)$.

Найбільш повно числовому дослідженню НДС та стійкості тонких пружних ортотропних повних тороїдальних оболонок (рис.3), що знаходяться під дією рівномірного зовнішнього тиску, присвячені роботи Ганєєвої М.С. та Косолапової Л.О. [11-14].

В роботах [12-14] розглянуто вплив на НДС та критичні навантаження геометричних параметрів тороїдальної оболонки постійної товщини, характеристик матеріалу та врахування деформацій поперечного зсуву. В співвідношеннях враховані геометрична нелінійність по теорії середнього прогину та деформація поперечного зсуву по теорії типу С.П. Тимошенко. Для розрахунку основного стану використовується канонічна система рівнянь, що враховує моментність та геометричну нелінійність. Нелінійна канонічна система розв'язується методом лінеаризації в поєднанні з методом додаткових функцій та ортогональної прогонки. При розрахунку повного тору використаним авторами методом постало запитання о постановці граничних умов на краях інтервалу інте-грування. Проведене дослідження впливу на НДС умов симетрії, поставлених на внутрішньому та зовнішньому екваторі оболонки пока-зало, ізотропної або ортотропної, що знаходиться під дією рівномірного зовнішнього тиску, результати розв'язання задачі визначення НДС не залежать від того, на якому екваторі - внутрішньому або зовнішньому, поставлені граничні умови симетрії.

Авторами визначені найбільші по меридіану прогини та найбільші по всьому об'єму оболонки напруження $\overline{\sigma_{11}}<\overline{\sigma_{22}}$ в момент вісесиметричної та невісесиметричної втрати стійкості для ортотропних тороїдальних оболонок постійної товщини з параметрами - $a / h_{0}=20,50$, 
$100 ; d / a=1,5 ; 2 ; 4 ; 8 ; 20, v_{12}=0,3,1 / G_{12}=2 \cdot(1+v 12), E_{2} / E_{1}=2 ; 1 ; 0,5$, де $E_{2}$ та $E_{1}$ - модулі пружності вздовж паралелі та меридіану відповідно. Виявлено, що найбільші напруження спостерігаються: $\overline{\sigma_{11}}-$ на внутрішній обмежуючій поверхні біля внутрішнього екватора, $\overline{\sigma_{22}}-$ на зовнішній обмежуючій поверхні в межах верхнього полюсу $\left(\bar{\sigma}=\frac{\sigma}{\mathrm{E}_{1}}\right)$.

В роботі [11] чисельно вирішена задача про великі прогини тонких кругової пружної ортотропної тороїдальної оболонки (рис. 4) змінної товщини під дією рівномірного зовнішнього тиску. В співвідношеннях поставленої автором задачі враховані геометрична нелінійність по теорії середнього прогину та деформація поперечного прогину по теорії типу С.П. Тимошенко.
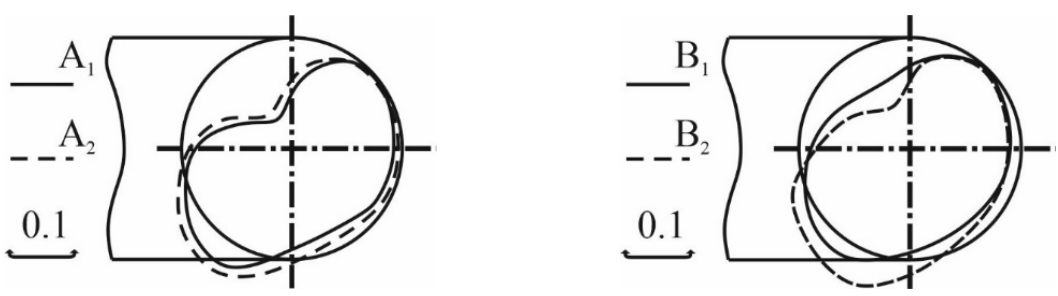

a)

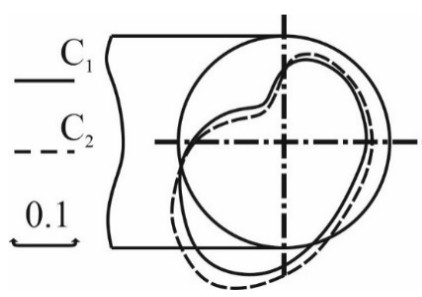

б)

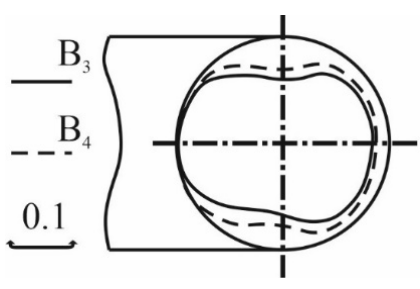

в)

Рис. 4. Епюри прогину для тороїдальної ортотропної оболонки постійної товщини з параметрами:

a) $E_{2} / E_{1}=2$; б) $E_{2} / E_{1}=0,5$; в) $E_{2} / E_{1}=1$

Для розрахунку основного НДС використані канонічні системи рівнянь. Нелінійна задача основного стану вирішена чисельно методом лінеаризації в сполучені з методом додаткових функцій та ортогональної прогонки. В якості ведучого параметру задачі використовується значення інтегрального прогину. Товщина оболонки вздовж меридіану задана формулою

$$
h(s)=h_{0} \cdot\left(\psi_{\ni}+a \cdot \cos ^{2} \theta\right),
$$


де $h_{0}$ - деяка характерна товщина оболонки;

$\psi_{\ni}$ - параметр;

$\psi_{c}=$ const;

$a=2 \cdot\left(\psi_{c}-\psi_{\ni}\right)$.

$\alpha$ визначається 3 умови рівності об'єму оболонки 3 постійною товщиною $h(s)=h_{0} \cdot \psi_{c}$, об'єму матеріалу оболонки з товщиною, заданою формулою (1).

В роботі [14] розглядається ізотропна тороїдальна оболонка виконана 3 металу. Система рівнянь рівноваги якої описується диференційними рівняннями загальної технічної моментної теорії В.З. Власова. Рішення даної задачі знаходилось в переміщеннях. Отримані результати представлено лише у вигляді наступних графіків:
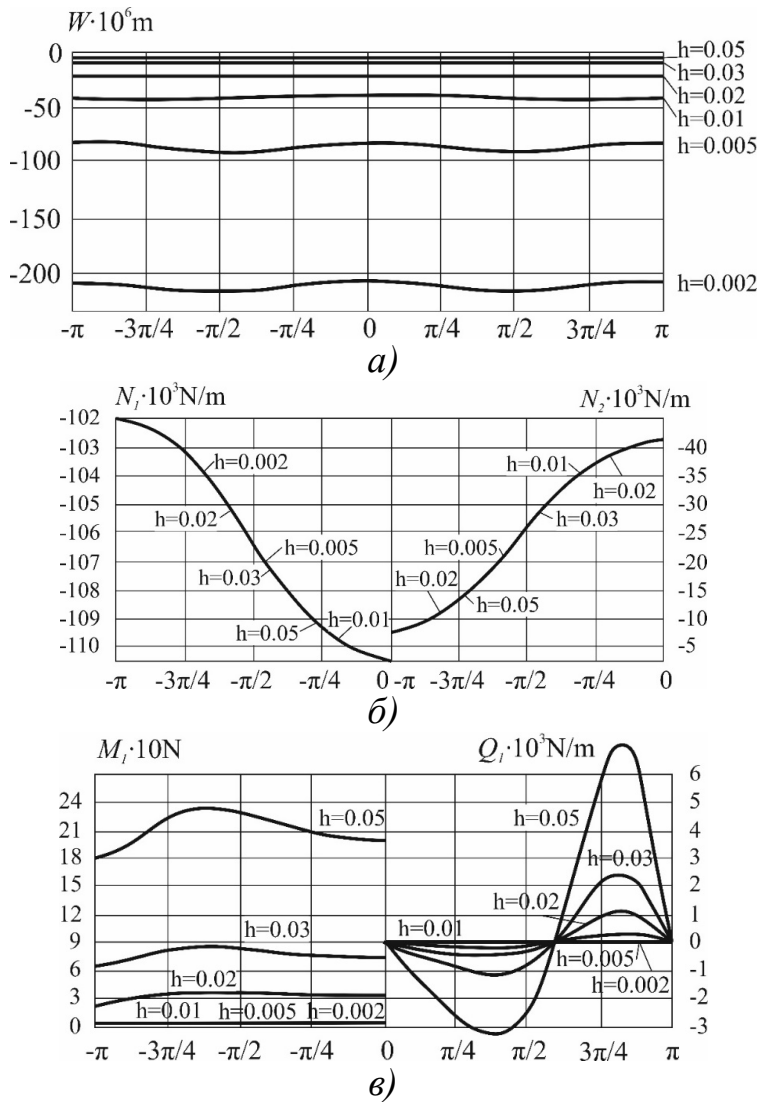

Рис. 5. Залежність напружено-деформованого стану тороїдальної оболонки від зміни товщини:

a) прогинів $W$; б) нормальних погонних зусиль $N_{1}$ ma $N_{2}$ в) згинаючого моменту $M_{1}$ та перерізуючої сили $Q_{1}$ 
ВІСНИК

ОДЕСЬКОГО НАЦІОНАЛЬНОГО

МОРСЬКОГО УНІВЕРСИТЕТУ
HERALD

OF THE ODESSA NATIONAL

MARITIME UNIVERSITY № $1(61), 2020$

Авторами роботи [15] наведено особливості розрахунку напружено-деформованого стану міцного корпусу підводного апарату в формі тору (рис.6) з круговим поперечним перерізом, який отримано методом поперечного намотування в комбінації $з$ повздовжньою намоткою (або викладкою) із полімерних композиційних матеріалів та 3 урахуванням змінної товщини по меридіанному перетину.

Встановлено вплив механічних властивостей компонентів композиційного матеріалу, порядку розташування армуючих шарів та геометрії тороїдального корпусу на його напружений стан. Це дозволить в разі оптимізації враховувати технологічні особливості створення композитного тороїдального міцного корпусу, отриманого методом безперервного намотування волокном.

Показано, що врахування різнотовщинності при намотуванні поперечних шарів, під час виконання поперечного намотування в комбінації з повздовжньою намоткою (або викладкою), суттєво впиває на величину та розподіл напружень по меридіанному перерізу в порівнянні 3 розрахунком по осередненій товщині. Встановлено, що максимально навантажена точка такого тороїдального міного корпусу завжди знаходиться на зовнішньому екваторі.
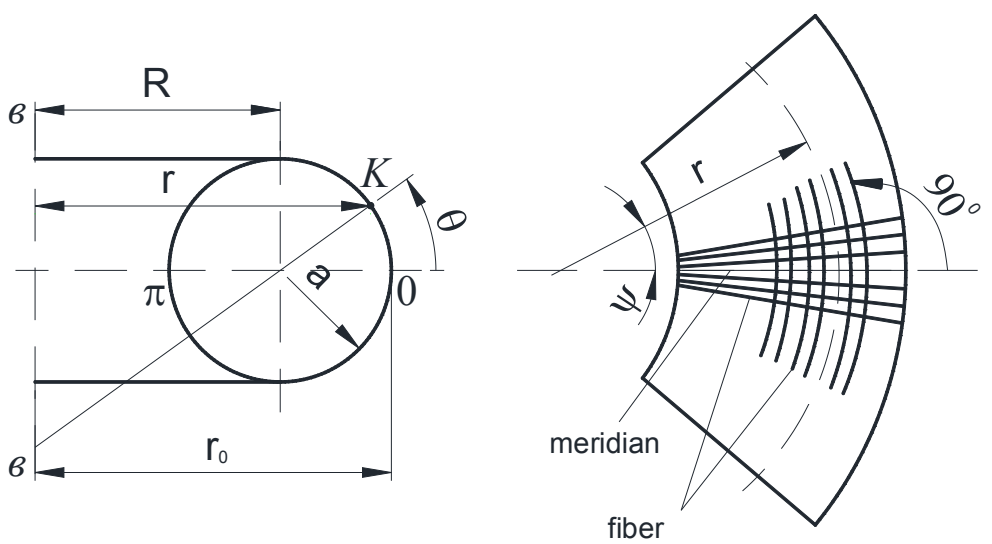

Рис. 6. Геометричні розміри та схеми намотування кругової тороїдальної оболонки виконаної поперечною намоткою в комбінації з поздовжньою намоткою (або викладкою): a- внутрішній радіус перерізу меридіана;

$R$ - відстань від вісі обертання до центру меридіанного перерізу; r0 - максимальний радіус обертання (на зовнішньому екваторі); $r$ - відстань від вісі обертання в-в до деякої точки $K(\theta)$ серединної поверхні у меридіанному перерізі 
А у роботі [16] наведено особливості напружено-деформованого стану міцного корпусу підводного технічного засобу у формі тору 3 круговим поперечним перерізом, який отримано методом спірального намотування із полімерних композиційних матеріалів.

У зв'язку з математичними труднощами врахування зміни кута намотування використовується метод осереднення як при геодезичному спіральному намотуванні, так і при рівноважному спіральному намотуванні, що стабілізує граничні значення модулів пружності.

Максимальні значення напружень серединної поверхні $\sigma_{\theta}$ для тороїдальних міцних корпусів в обох варіантах спірального намотування будуть на внутрішньому екваторі (рис. 6) меридіанного перерізу $(\theta=\pi)$, а для напружень $\sigma_{\psi}$ будуть на зовнішньому екваторі меридіанного перерізу $\left(\theta=0^{\circ}\right)$. Хоча для тороїдального міцного корпусу, виконаного поперечним намотуванням в комбінації з повздовжнім намотуванням (або викладкою), максимальні значення напружень серединної поверхні $\sigma_{\theta}$ i $\sigma_{\psi}$ будуть на зовнішньому екваторі меридіанного перерізу $\left(\theta=0^{\circ}\right)$.

Всі рішення в роботах $[15 ; 16]$ представлені в чисельному вигляді.

\section{Висновки}

1. Проаналізовано стан проблеми проектування міцних корпусів із полімерних композиційних матеріалів для підводних апаратів та визначені основні переваги тороїдального міцного корпусу, що полягають у його гідродинамічній формі, можливості виготовлення корпусу методом намотування, малою чутливістю щодо недосконалості геометрії. Показані приклади практичного застосування тороїдальних корпусів для підводних апаратів.

2. Розглянуті дослідження НДС тороїдальних ізотропних та ортотропних оболонок постійної та змінної товщини, наведені епюри прогину для тороїдальної ортотропної оболонки постійної товщини та залежністі напружено-деформованого стану тороїдальної оболонки від зміни товщини.

3. Наведено особливості розрахунку напружено-деформованого стану міцного корпусу підводного апарату в формі тору з круговим поперечним перерізом, який отримано методом поперечного намотування в комбінації з повздовжньою намоткою (або викладкою) із полімерних композиційних матеріалів та 3 урахуванням змінної товщини по меридіанному перетину.

4. Встановлено вплив механічних властивостей компонентів композиційного матеріалу, порядку розташування армуючих шарів та геометрії тороїдального корпусу на його напружений стан. Це дозволить в разі оптимізації враховувати технологічні особливості створення 
композитного тороїдального міцного корпусу, отриманого методом безперервного намотування волокном.

5. Розглянуті особливості напружено-деформованого стану міцного корпусу підводного технічного засобу у формі тору з круговим поперечним перерізом, який отримано методом спірального намотування iз полімерних композиційних матеріалів та особливості використання методу осереднення, для його розрахунку.

\section{СПИСОК ЛІТЕРАТУРИ}

1. Крептюк А.В. Перспективы метода намотки как способа создания прочных корпусов подводных конструкиий и аппаратов / А.В. Крептюк // Проблеми техніки: Науково-виробничий журнал. 2012. № 4. С. 133-148.

2. Пат. 04043190A Японії, MKI B63G 8/00. Large-sized submersible vessel / Baba Eiichi (Mitsubishi Heavy Ind LTD). № 02150698; Заява 08.06.1990. Опубл. 13.02.1992.

3. Прокофьев С. Подводные средства сил специальных операций зарубежных стран / С. Прокофьев // Зарубежное военное обозрение. № 10 1998. С. 38-46.

4. Патент на корисну модель №78215, Україна, ММК (2013.01) B63G8/00. Підводне судно типу «Пірнаюче блюдие» підвищеної маневреності / С.Т. Бурдун, А.В. Крептюк; Начіональний університет кораблебудування ім. адмірала Макарова. № U2012 10913; заявл. 18.09.2012; опубл. 11.03.2013 // Промислова власність, 2013. - Бюл. № 5.

5. Energy systems of extended endurance in the 1-100 kilowatt range for undersea applications: a report National Research Council (U.S.). Committee on Undersea Warfare. Panel on Energy Sources National Academies, 1968. - P. 132.

6. Concept Design for a Manned Underwater Station / Defense Technical Information Center, 1967. - P. 234.

7. Alan I. Prescott. Ocean Engineering Research Advances / P.I. Alan // Nova Publishers, 2008. - 334 p.

8. Черных К.Ф. Расчет торообразных оболочек. Сб. «Исследования по упругости и пластичности» / К.Ф. Черных, В.А. Шамина // 2, изд. ЛГУ, 1963.

9. Бурдун Е.T. Рациональное проектирование композитного прочного корпуса тороидальной формы для технических средств освоения океана / Е.Т. Бурдун, А.В. Крептюк // Вестник АГТУ. Сер. Морская техника и технология. - 2014. № 2. - C. 27-36. 
ВІСНИК

ОДЕСЬКОГО НАЦІОНАЛЬНОГО

МОРСЬКОГО УНІВЕРСИТЕТУ

№ 1 (61), 2020
HERALD

OF THE ODESSA NATIONAL

MARITIME UNIVERSITY

№ $1(61), 2020$

10. Ганеева М.С. Численное исследование устойчивости ортотропных тороидальных оболочек переменной толщины / М.С. Ганеева, Л.А. Косолапова // Исследования по теории оболочек: Труды семинара. - Bып. XXI, ч. I. - Казань, 1988. C. 23-36.

11. Ганеева М.С. Нелинейный изгиб и устойчивость тонких упругих ортотропных тороидальных оболочек под действием равномерного внешнего давления / М.С. Ганеева, Л.А. Косолапова // Прочн. и устойчивость оболочек. Тр. семин. Казан. физ.-техн. ин-та. Bып. 19. Ч. 1. Казань, 1986. - C. 23-26.

12. Ганеева М.С. Прочность и устойчивость оболочек вращения / М.С. Ганеева // М.: Наука, 1992.

13. Ганеева М.С. Численное исследование напряженно-деформированного состояния и устойчивости ортотропныл тороидальных оболочек / М.С. Ганеева, Л.А. Косолапова // Казань, 1985. 26 c. - Деп. в ВИНИТИ 29.01.85, № 864-85 ДЕП.

14. Гребенюк С.Н. Напряженно-деформированное состояние тороидальных оболочек / С.Н. Гребенюк, Ю.А. Сысоев, Н.Ю. Сысоев // Вестник Запорожского начионального универcumema. - 2010. - № 2 - C 24-28.

15. Sizonenko O.Peculiarities of stress-strain state of toroidal pressure hull, made by winding / Sizonenko O., Burdun E., Prystash S.//International journal for science, technics and innovations for the industry. Machines, Technologies, Materials, Year XII Issue 6/2018. - P. 240-243.

16. Sizonenko O. Peculiarities of stress-strain state of toroidal pressure hull, made by spiral winding / Sizonenko O., Burdun E., Prystash S. // International journal for science, technics and innovations for the industry. Machines, Technologies, Materials, PRINT ISSN 1313 - 0226, ISSN WEB 1314-507X, Year XII, Issue 11/2018. - P. 466-469.

\section{REFERENCES}

1. Kreptyuk A.V. (2012) Perspektivy` metoda namotki kak sposoba sozdaniya prochnykh korpusov podvodny'kh konstrukczij $i$ apparatov. Problemi tekhni ki: Naukovo-virobnichij zhurnal. № 4. S. 133-148. (in Russian).

2. Baba Eiichi. Large-sized submersible vessel. Mitsubishi Heavy Ind LTD, assignee, Patent of Japan №02150698, 13.February. 1992.

3. Prokof'ev S. (1998) Podvodny'e sredstva sil speczial'ny'kh operaczij zarubezhny kh stran. Zarubezhnoe voennoe obozrenie Vol. 10. P.38-46. 
4. Ye.T. Burdun, A.V. Kreptiuk. Pidvodne sudno typu «Pirnaiuche bliudtse» pidvyshchenoi manevrenosti [Submersible sailboat of high maneuverability], Admiral Makarov National University of Shipbuilding, assignee, Patent of Ukraine UA 10913. 11 March 2013.

5. Energy systems of extended endurance in the 1-100 kilowatt range for undersea applications: a report National Research Council (U.S.). Committee on Undersea Warfare. Panel on Energy Sources National Academies (1968). P. 132.

6. Concept Design for a Manned Underwater Station / Defense Technical Information Center, (1967), P. 234.

7. Alan I. Prescott (2008) Ocean Engineering Research Advances. Nova Publishers, $334 \mathrm{p}$.

8. Cherny 'kh K.F. Shamina V.A. (1963) Raschet toroobrazny'kh obolochek. Sb. «Issledovaniya po uprugosti i plastichnosti», 2, izd. (in Russian).

9. Burdun E.T., Kreptyuk A.V. (2014) Raczional noe proektirovanie kompozitnogo prochnogo korpusa toroidal'noj formy' dlya tekhnicheskikh sredstv osvoeniya okeana. Vestnik AGTU. Ser. Morskaya tekhnika i tekhnologiya. Vol. 2. -P. 27-36.

10. Ganeeva M.S. Kosolapova L.A. (1988) Chislennoe issledovanie ustojchivosti ortotropny $k$ h toroidal 'ny $k h$ obolochek peremennoj tolshhiny. Issledovaniya po teorii obolochek: Trudy' seminara. Vy'p. KhKhI, ch. I. - Kazan`. P. 23-36. (in Russian).

11. Ganeeva M.S., Kosolapova L.A. (1986) Nelinejny j izgib i ustojchivost' tonkikh uprugikh ortotropny'kh toroidal ny 'kh obolochek pod dejstviem ravnomernogo vneshnego davleniya. Prochn. $i$ ustojchivost obolochek. Tr. semin. Kazan. fiz.-tekhn. in-ta. Vy 'p. 19. Ch. 1, Kazan! P. 23-26. (in Russian).

12. Ganeeva M.S. (1992) Prochnost' $i$ ustojchivost' obolochek vrashheniya. M.: Nauka. (in Russian).

13. Ganeeva M.S., Kosolapova L.A. (1985) Chislennoe issledovanie napryazhenno-deformirovannogo sostoyaniya $i$ ustojchivost $i$ ortotropny kh toroidal ny kh obolochek / M.S. Ganeeva, L.A. Kosolapova // Kazan`, 26 p. - Dep. v VINITI 29.01.85, № 864-85 DEP. (in Russian).

14. Grebenyuk S.N., Sy`soev Yu.A., Sy`soev N.Yu. (2010). Napryazhenno-deformirovannoe sostoyanie toroidal ny $k h$ obolochek. Vestnik Zaporozhskogo naczional nogo universiteta. № 2 . P. 24-28. (in Russian). 
ВІСНИК

ОДЕСЬКОГО НАЦІОНАЛЬНОГО

МОРСЬКОГО УНІВЕРСИТЕТУ

№ 1 (61), 2020
HERALD

OF THE ODESSA NATIONAL

MARITIME UNIVERSITY

№ $1(61), 2020$

15. Sizonenko O., Burdun E., Prystash S. (2018) Peculiarities of stress-strain state of toroidal pressure hull, made by winding. International journal for science, technics and innovations for the industry. Machines, Technologies, Materials, Year XII Issue 6. P. 240-243.

16. Sizonenko O., Burdun E., Prystash S. (2018) Peculiarities of stress-strain state of toroidal pressure hull, made by spiral winding. International journal for science, technics and innovations for the industry. Machines, Technologies, Materials, PRINT ISSN 1313 - 0226, ISSN WEB 1314-507X, Year XII, IsSue 11. P. 466-469.

Стаття надійшла до редакиії 20.02.20

Посилання на статтю: Присташ С.Ф. Аналіз стану та проблем розрахунку напружено-деформованого стану тороїдального міцного корпусу для підводних апаратів // Вісник Одеського національного морського університету: 3б. наук. праць, 2020. № 1(61). C. 55-69. DOI 10.47049/2226-1893-2020-1-55-69.

Article received 20.02.20

Reference a JournalArtic: Prystash, S. Analysis of the state and problems of evaluation of stressed-deformed state of toroidal pressure hull for underwater apparats. 1(61), 55-69 // Herald of the Odessa national maritime university. DOI 10.47049/22261893-2020-1-55-69. 